\title{
RELA wt Allele
}

National Cancer Institute

\section{Source}

National Cancer Institute. RELA wt Allele. NCI Thesaurus. Code C53116.

Human RELA wild-type allele is located in the vicinity of $11 \mathrm{q} 13$ and is approximately $9 \mathrm{~kb}$ in length. This allele, which encodes transcription factor p65 protein, plays a role in the modulation of transcription by RNA polymerase II. Infrequently, lymphoproliferative disorders are associated with the translocation $\mathrm{t}(11 ; 14)(\mathrm{q} 14 ; \mathrm{q} 32)$ of this gene.

Amplification or increased expression of this gene has also been noted in some cases of squamous carcinomas of the head and neck and adenocarcinomas of the breast and stomach. 